\title{
BUSINESS MANAGEMENT VIA MEASURING HOW MUCH CORPORATE TAX AFFECT RISK IN VIET NAM AIRLINES AND TOURISM INDUSTRY
}

\author{
DINH TRAN NGOC HUY ${ }^{1}$, DO MINH PHUONG ${ }^{2}$, DUONG THI HONG NHUNG ${ }^{3}$, PHAM MINH DAT ${ }^{4}$ \\ ${ }^{1}$ Research Scholar, Banking University, Ho Chi Minh city, Vietnam \\ ${ }^{2}$ Research Scholar, Thuongmai University, Hanoi, Vietnam \\ ${ }^{3}$ Research Scholar, Thuongmai University, Hanoi, Vietnam \\ ${ }^{4}$ Research Scholar, Thuongmai University, Hanoi, Vietnam
}

\begin{abstract}
Over past few years, the global financial crisis shows certain influence on emerging financial markets including Vietnam. Therefore, this study chooses an analytical approach to give some systematic opinions on business management and risk management in Vietnam tourism industry under different scenarios of tax policy.

First, it calculates equity and asset beta values in three (3) different scenarios of changing tax rate. It implies that to reduce risk, these listed tourism companies need to enhance governance and business management capability. Second, under 3 different scenarios of changing tax rates $(20 \%, 25 \%$ and $28 \%)$, we recognized that there is not large disperse in equity beta values. It means that business management need to propose management strategies based on controlling risk better.

Third, by changing tax rates in 3 scenarios (25\%, 20\% and 28\%), we recognized both equity and asset beta mean values have positive relationship with the increasing level of tax rate.

Last but not least, this paper covers some ideas and policy suggestions, both for better management of tourism companies and for economy.

JEL classification numbers: G00, G3, G30

KEYWORDS: Risk Management, Business Management, Asset Beta, Financial Crisis, Corporate Tax, Policy
\end{abstract}

Received: Jun 01, 2020; Accepted: Jun 20, 2020; Published: Jun 30, 2020; Paper Id.: IJMPERDJUN2020140

\section{INTRODUCTION}

After financial crisis and reactions in financial industry taking place recently, we find out that there are signals of impacts of tax rates and the level of financial leverage on the fluctuations of market risk, measured by both equity and asset beta values. This leads to a question on using external debt of management team in a hope that the business market value can be recovered. Despite of trying to select an easy-reading writing style, there is still some academic words need to be explained in further.

The organization of paper contents is as following. As our previous series of paper, Research literature, issues, methodology and theories are covered in the first two sessions. Next, it followed by introduction of our empirical findings in session $3\left(3^{\text {rd }}\right)$. Continuously, session four (4) covers conclusion and policy suggestion. Before last, there are exhibit session which covers some calculated results of this paper's analysis and comparison. 


\section{PRELIMINARY NOTES}

\section{Research Issues}

This research aims to figure out two (2) issues:

- Issue 1: What happen to asset beta if both FL and tax rate change in 3 scenarios

- Issue 2: What happen to equity beta if both FL and tax rate change in 3 scenarios

\section{LITERATURE REVIEW}

John (1999) mentions a two-rate tax system where land is taxed at a higher rate than structures in his research on two-rate property tax effects on land development.

Anderson (2009) recognized that the user cost tax elasticities are relatively small while the expected house price inflation elasticity is substantially larger and therefore plays a greater role in affecting housing market demand.

Beside, Modigliani and Mill (1963) show that firm value is an increasing function of leverage due to the tax deductibility of interest payments at the corporate level. Carr and $\mathrm{Wu}$ (2011) stated that equity volatility increases proportionally with the level of financial leverage, the variation of which is dictated by managerial decisions on a company's capital structure based on economic conditions. And, irrespective of financial leverage, a positive shock to business risk increases the cost of capital and reduces the valuation of future cash flows, generating an instantaneous negative correlation between asset returns and asset volatility.

McCarty (2012) stated there is evidence which suggests that for the most tax risky firms investors also apply a higher discount rate to estimations of future cash flows. Then, Vello and Martinez (2012) indicated there is a negative and significant relation between the market risk and the tax planning efficiency index of firms that have good governance practices.

Next, Madhou (2012) found out, for Australia firms over the period 2003-2008, those with low leverage appear to hold higher cash holdings than high leverage ones. Then, McCauley (2013) pointed that during calm periods, portfolio investment by real money and leveraged investors in advanced countries flow into emerging markets, leading to an asymmetric asset swap (risky emerging market assets against safe reserve currency assets) and leveraging up by emerging market central banks. Last but not least, Gunarathna (2013) found out in different industries in Sri Lanka, firm size does not significantly affect the financial risk, but the degree of financial leverage has a significant positive correlation with financial risk.

\section{CONCEPTUAL THEORIES}

The tax system not only responds to the globalization but also affects national income, investment levels and risks of doing business. Furthermore, tax system can affect the investment return and the ratio of re-investment and business growth.

The using of leverage also could create both negative and positive effects on business operational results. A firm will make decision on significant amount of debt when it hopes ROA will be higher than the lending interest. Using leverage might affect both company performance and its risk. 


\section{METHODOLOGY}

In this research, analytical research method is used, philosophical method is used and specially, scenario analysis method is used. Analytical data is from the situation of listed banking industry firms in VN stock exchange and applied current tax rate is $25 \%$.

\section{MAIN RESULTS}

\section{Empirical Research Findings and Discussions}

Data used are from total 10 listed tourism industry companies on VN stock exchange (HOSE and HNX mainly). In the scenario 1, current tax rate is kept as $25 \%$ as in the 2011 financial statements which is used to calculate market risk (beta) while leverage degree is kept as current, then changed from $30 \%$ up to $20 \%$ down. Then, two (2) FL scenarios are changed up when tax rate is up to $30 \%$ and down to $20 \%$. In summary, the below table 1 shows three (3) scenarios used for analyzing the risk level of these listed firms.

Market risk (beta) under the impact of tax rate, includes: 1) equity beta; and 2) asset beta.

Table 1: Analyzing Market Risk Under Three (3) Scenarios (Made by Author)

\begin{tabular}{|l|l|l|l|}
\hline & Tax Rate as Current (25\%) & Tax Rate Up to 30\% & Tax Rate Down Tto 20\% \\
\hline $\begin{array}{l}\text { Leverage as } \\
\text { current }\end{array}$ & Scenario 1 & Scenario 2 & Scenario 3 \\
\hline
\end{tabular}

\section{A. Scenario 1: Current Tax Rate 25\% and Leverage Kept as Current}

In this case, all beta values of 10 listed firms on VN airline and tourism industry market as following:

Table 2: Market Risk of Listed Companies on VN Airline and Tourism Industry Market Under A Two Factors Model (Case 1) (Source: VN Stock Exchange 2012)

\begin{tabular}{|c|c|c|c|}
\hline \multirow{2}{*}{ Order No. } & \multirow{2}{*}{ Company Stock Code } & \multicolumn{2}{|c|}{ Leverage as Current } \\
\cline { 3 - 4 } & & Equity Beta & Asset Beta (Assume Debt Beta = 0) \\
\hline 1 & CTC & 0,226 & 0,072 \\
\hline 2 & DLC & 0,475 & 0,281 \\
\hline 3 & DLV & 0,719 & 0,264 \\
\hline 4 & FDT & 0,764 & 0,300 \\
\hline 5 & HOT & 1,447 & 1,222 \\
\hline 6 & PDC & 2,035 & 1,298 \\
\hline 7 & PGT & 1,648 & 1,532 \\
\hline 8 & TCT & 1,016 & 0,913 \\
\hline 9 & TTR & $-1,060$ & $-0,888$ \\
\hline 10 & MAS & 0,382 & $\mathbf{0 , 1 4 3}$ \\
\hline
\end{tabular}

\section{B. Scenario 2: Tax Rate Increases Up To $28 \%$ and Leverage Kept as Current}

All beta values of total 10 listed firms on $\mathrm{VN}$ airline and tourism industry market as below:

Table 3: Market Risks of Listed Airline and Tourism Industry Firms Under

A Two Factors Model (Case 2) (Source: VN Stock Exchange 2012)

\begin{tabular}{|c|c|c|c|}
\hline \multirow{2}{*}{ Order No. } & \multirow{2}{*}{ Company Stock Code } & \multicolumn{2}{|c|}{ Leverage as Current } \\
\cline { 3 - 4 } & Cquity Beta & Asset Beta (Assume Debt Beta = 0) \\
\hline 1 & DLC & 0,226 & 0,072 \\
\hline 2 & DLV & 0,492 & 0,292 \\
\hline 3 & FDT & 0,735 & 0,270 \\
\hline 4 & HOT & 1,450 & 0,307 \\
\hline 5 & PDC & 2,035 & 1,228 \\
\hline 6 & & & 1,298 \\
\hline
\end{tabular}




\begin{tabular}{|c|c|c|c|}
7 & PGT & 1,648 & 1,532 \\
\hline 8 & TCT & 1,016 & 0,913 \\
\hline 9 & TTR & $-1,060$ & $-0,888$ \\
\hline 10 & MAS & 0,382 & $\mathbf{0 , 1 4 3}$ \\
\hline
\end{tabular}

\section{Scenario 3: Tax Rate Decreases Down to $20 \%$ and Leverage Kept as Current}

All beta values of total 10 listed firms on VN airline and tourism industry market as below:

Table 4: Market Risks of Listed Airline and Tourism Industry Firms Under

A Two Factors Model (Case 3) (Source: VN Stock Exchange 2012)

\begin{tabular}{|c|c|c|c|}
\hline \multirow{2}{*}{ Order No. } & \multirow{2}{*}{ Company Stock Code } & \multicolumn{2}{|c|}{ Leverage As Current } \\
\cline { 3 - 4 } & Equity Beta & Asset Beta (Assume Debt Beta = 0) \\
\hline 1 & CTC & 0,226 & 0,072 \\
\hline 2 & DLC & 0,447 & 0,265 \\
\hline 3 & DLV & 0,693 & 0,254 \\
\hline 4 & FDT & 0,737 & 0,290 \\
\hline 5 & HOT & 1,436 & 1,212 \\
\hline 6 & PDC & 2,035 & 1,298 \\
\hline 7 & PGT & 1,648 & 1,532 \\
\hline 8 & TCT & 1,016 & 0,913 \\
\hline 9 & TTR & $-1,060$ & $-0,888$ \\
\hline 10 & MAS & 0,382 & $\mathbf{0 , 1 4 3}$ \\
\hline
\end{tabular}

All three above tables and data show that there are just tiny changes in the values of equity beta and there are bigger fluctuations in the values of asset beta in the three (3) cases.

Comparing Statistical Results in 3 Scenarios of Changing Leverage

Table 5: Statistical Results (FL in Case 1) (Source: VN Stock Exchange 2012)

\begin{tabular}{|c|c|c|c|}
\hline & \multicolumn{3}{|c|}{ Leverage As Current } \\
\hline $\begin{array}{c}\text { Statistic } \\
\text { Results }\end{array}$ & $\begin{array}{c}\text { Equity } \\
\text { Beta }\end{array}$ & Asset Beta (Assume Debt Beta = 0) & Difference \\
\hline MAX & 2,035 & 1,532 & 0,503 \\
\hline MIN & $-1,060$ & $-0,888$ & $-0,173$ \\
\hline MEAN & 0,765 & 0,514 & 0,251 \\
\hline VAR & 0,7530 & 0,5302 & 0,223 \\
\hline Note: Sample size : 10 firms \\
\hline
\end{tabular}

Table 6: Statistical Results (Fl in Case 2) (Source: VN Stock Exchange 2012)

\begin{tabular}{|c|c|c|c|}
\hline & \multicolumn{2}{|c|}{ Leverage as Current } & \\
\hline $\begin{array}{c}\text { Statistic } \\
\text { Results }\end{array}$ & $\begin{array}{c}\text { Equity } \\
\text { Beta }\end{array}$ & Asset Beta (Assume Debt Beta = 0) & Difference \\
\hline MAX & 2,035 & 1,532 & 0,503 \\
\hline MIN & $-1,060$ & $-0,888$ & $-0,173$ \\
\hline MEAN & 0,771 & 0,517 & 0,254 \\
\hline VAR & 0,7528 & 0,5299 & 0,223 \\
\hline \multicolumn{4}{|l}{ Note: Sample size : 10 firms } \\
\hline
\end{tabular}


Table 7: Statistical Results (FL in Case 3) (Source: VN Stock

Exchange 2012)

\begin{tabular}{|c|c|c|c|}
\hline & \multicolumn{3}{|c|}{ Leverage as Current } \\
\hline $\begin{array}{c}\text { Statistic } \\
\text { Results }\end{array}$ & $\begin{array}{c}\text { Equity } \\
\text { Beta }\end{array}$ & Asset Beta (Assume Debt Beta = 0) & Difference \\
\hline MAX & 2,035 & 1,532 & 0,503 \\
\hline MIN & $-1,060$ & $-0,888$ & $-0,173$ \\
\hline MEAN & 0,756 & 0,509 & 0,247 \\
\hline VAR & 0,7534 & 0,5305 & 0,223 \\
\hline \multicolumn{2}{|l}{ Note: Sample size : 10 firms } \\
\hline
\end{tabular}

The above calculated figures generate some following results:

First of all, Equity beta mean values in all 3 scenarios are acceptable $(<0,9)$ and asset beta mean values are also small $(<0,7)$. If leverage increases to $30 \%$, asset beta max values keep the same value of 1,497 when tax rate is up to $28 \%$ or down to $20 \%$. Finally, when leverage decreases down to $20 \%$, asset beta max values keep the same value of 1,555 in both cases: tax rate up and down.

The below chart 1 shows us : when leverage degree decreases down to $20 \%$, if tax rate is up to $28 \%$, average equity beta value increases slightly $(0,837)$ compared to that at the decrease of tax rate of $20 \%(0,822)$. However, equity beta $\operatorname{var}$ is 0,754 (tax rate up), little higher than 0,752 (tax rate down). Then, when leverage degree increases up to $30 \%$, if tax rate is up to $28 \%$, average equity beta increases little (to 0,667 ) compared to that at the decrease of tax rate of $20 \%$ $(0,656)$. However, in case the tax rate up, the equity beta var is 0,787 , smaller than 0,790 (tax rate down).

The below chart 2 shows us : when leverage degree decreases down to $20 \%$, if tax rate is up to $28 \%$, average asset beta value increases slightly $(0,606)$ compared to that at the decrease of tax rate of $20 \%(0,597)$. However, asset beta var is 0,557 (tax rate up), the same as that in the case of tax rate down. Then, when leverage degree increases up to $30 \%$, if tax rate is up to $28 \%$, average asset beta also increases little more (to 0,606 ) compared to that at the decrease of tax rate of $20 \%$ $(0,597)$. However, in case the tax rate up, the asset beta var is 0,497 , higher than 0,495 (tax rate down).

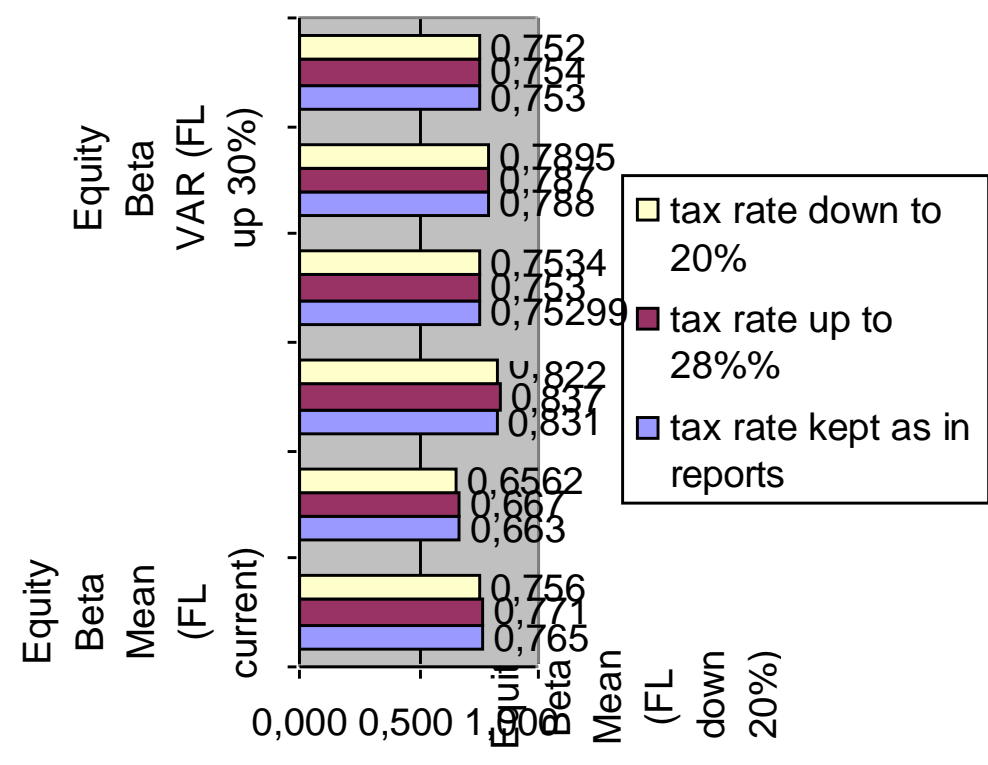

Figure 1: Comparing Statistical Results of Equity Beta Var and Mean in Three (3) Scenarios of Changing FL and Tax Rate (Source: VN Stock Exchange 2012) 


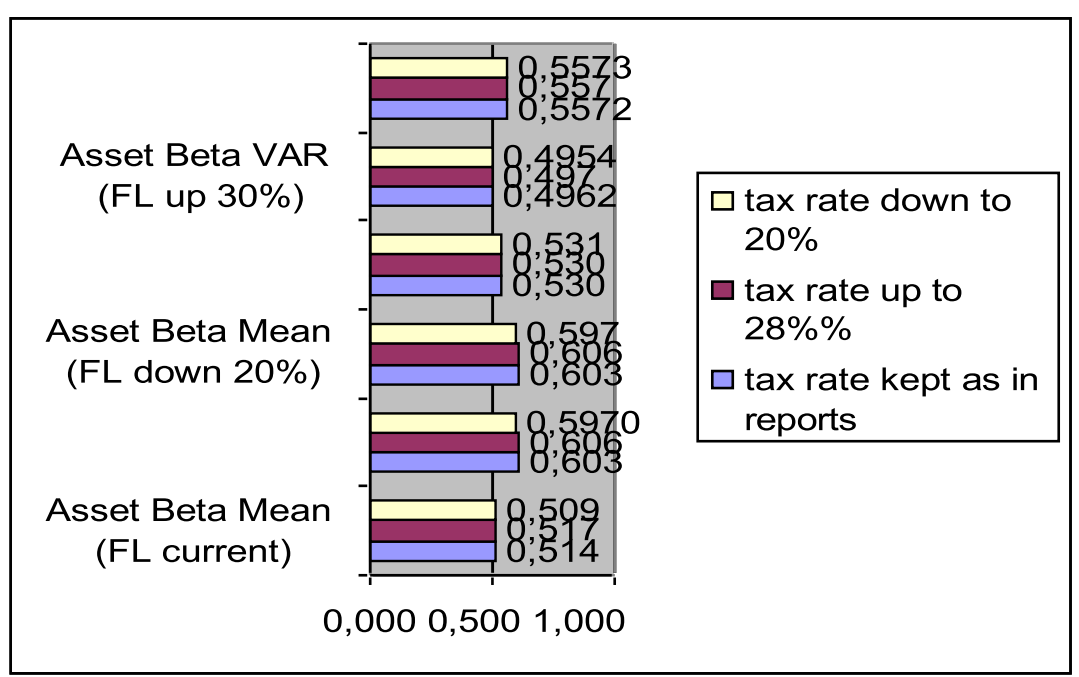

Figure 2: Comparing Statistical Results of Asset Beta Var and Mean in Three (3) Scenarios of Changing FL and Tax Rate (Source: VN Stock Exchange 2012)

\section{CONCLUSIONS AND POLICY SUGGESTIONS}

In summary, the government has to consider the impacts on the movement of market risk in the markets when it changes the macro policies and the legal system and regulation for developing the tourism market. The Ministry of Finance continues to increase the effectiveness of fiscal policies and tax policies which are needed to combine with other macro policies at the same time. The State Bank of Viet Nam continues to increase the effectiveness of capital providing channels for tourism companies as we might note that in this study when leverage is going to increase up to $30 \%$, the risk level decreases (asset beta mean decreases to 0,597 if tax rate moves down to $20 \%$ ).

Furthermore, the entire efforts among many different government bodies need to be coordinated. Finally, this paper suggests implications for further research and policy suggestion for the Viet Nam government and relevant organizations, economists and investors from current market conditions.

\section{ACKNOWLEDGEMENTS}

I would like to take this opportunity to express my warm thanks to Board of Editors and Colleagues at Citibank -HCMC, SCB and BIDV-HCMC, Dr. Chen and Dr. Yu Hai-Chin at Chung Yuan Christian University for class lectures, also Dr Chet Borucki, Dr Jay and my ex-Corporate Governance sensei, Dr. Shingo Takahashi at International University of Japan. My sincere thanks are for the editorial office, for their work during my research. Also, my warm thanks are for Dr. Ngo Huong, Dr. Ho Dieu, Dr. Ly H. Anh, Dr Nguyen V. Phuc and my lecturers at Banking University - HCMC, Viet Nam for their help. Lastly, thank you very much for my family, colleagues, and brother in assisting convenient conditions for my research paper.

\section{REFERENCES}

1. Allen, F., and Gale, D., Stock Price Manipulation, Review of Financial Studies, (1992).

2. Ameer, Beenish., and Jamil, Moazzam., (2013), A Test of Fama and French Three Factor Model in Pakistan Equity Market , Global Journal of Management and Business Research, Vol.13, Issue 7, pp. 24-28

3. Baker, Kent H., Singleton, Clay J., and Veit, Theodore E., (2011), Survey Research in Corporate Finance: Bridging The Gap 
Between Theory and Practice, Oxford University Press

4. Basu, Devraj., Streme, Alexander., (2007), CAPM and Time-Varying Beta: The Cross-Section of Expected Returns, SSRN Working paper series

5. Chatterjea, Arkadev., Jerian, Joseph A., and Jarrow, Robert A., Market Manipulation and Corporate Finance: A new Perspectives, 1994 Annual Meeting Review, SouthWestern Finance Association, Texas, USA, (2001).

6. DeGennaro, Ramon P., Kim, Sangphill., (2003), The CAPM and Beta in an Imperfect Market, SSRN Working paper series

7. Flifel, Kaouther., (2012), Financial Markets between Efficiency and Persistence : Empirical Evidence on Daily Data, Asian Journal of Finance and Accounting

8. Galagedera, D.U.A., (2007),An alternative perspective on the relationship between downside beta and CAPM beta, Emerging Markets Review

9. Huy, Dinh T.N., (2013), Whether The Risk Level of Viet Nam Real Estate Firms Under The Different Changing Tax Rates Increase or Decrease So Much, International Journal of Research in Business and Technology

10. Khwaja, Asim Ijaz., Mian, Atif., Unchecked intermediaries:Price manipulation in an emerging stock market, Journal of Financial Economics 78, (2005), 243 - 241

11. Marchesi, Michael Favere., The Impact of Tax Services on Auditors' Fraud Risk Assessments, Advances in Accounting

12. BIRIOWU, CHRIS S., and JOHN E. CHIKWE. "EXAMINATION OF BASIC DATA MEASUREMENT SCALES AND STATISTICAL TECHNIQUES TESTS RELEVANCE IN CONTEMPORARY BUSINESS MANAGEMENT RESEARCH: A DISCOURSE." International Journal of Business Management \& Research (IJBMR) 8.5 (2018):39-54

13. Pal, Shrabanti. "Behaviour of Financial Metrics of Indian Steel Industry During Pre And Post Financial Crisis Period." International Journal of Financial Management (IJFM) 5.4 (2016): 11-22.

14. DERBALI, ABDELKADER, and SLAHEDDINE HALLARA. "Main determinants of banking profitability in Tunisia before and during the financial crisis of 2007." International Journal of Accounting and Financial Management Research (IJAFMR) 3.1 (2013): 39-56.

15. Research

16. Ang, A., Chen, J., (2007), CAPM Over the Long Run: 1926-2001, Journal of Empirical Finance

17. ADB and Viet Nam Fact Sheet, 2010

18. Other web sources

19. http://www.ifc.org/ifcext/mekongpsdf.nsf/Content/PSDP22

20. http://www.construction-int.com/article/vietnam-construction-market.html

21. http://fia.mpi.gov.vn/Default.aspx?ctl=Article\&MenuID $=170 \& a I D=185 \&$ PageSize $=10 \&$ Page $=0$

22. http://kientruc.vn/tin_trong_nuoc/nganh-bat-dong-san-rui-ro-va-co-hoi/4881.html

23. http://www.bbc.co.uk/vietnamese/vietnam/story/2008/12/081226_vietnam_gdp_down.shtml

24. http://www.mofa.gov.vn/vi/ 


\section{Exhibit}

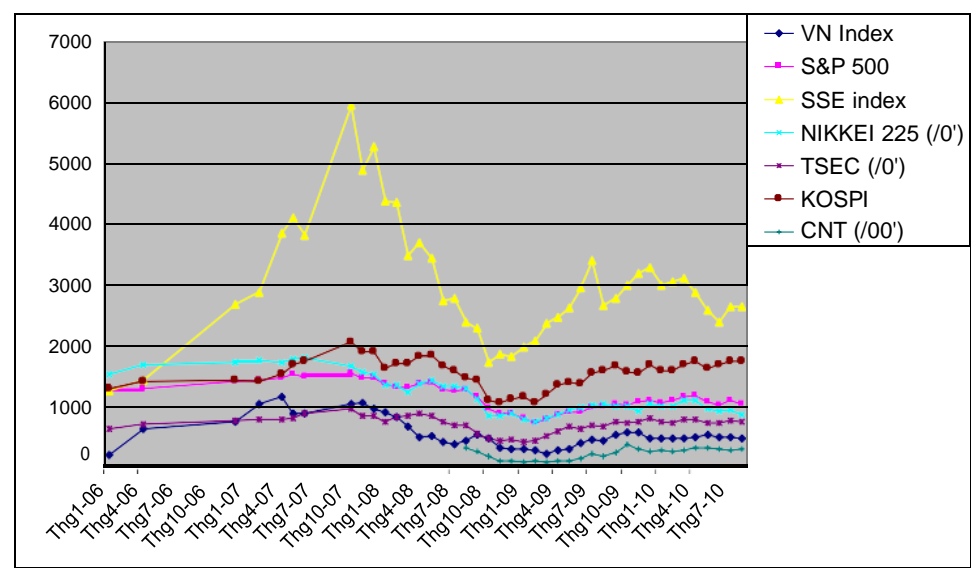

Exhibit 1: VNI Index aIndex During Crisis 2006-2010 (Source: Global Stock Exchange 2012)

Exhibit 2: Comparable Firms and Changing Leverage for Viet Nam Airline and Tourism Firms (Source: Viet Nam Stock Exchange 2012)

\begin{tabular}{|c|c|c|c|c|c|}
\hline $\begin{array}{c}\text { Order } \\
\text { No. }\end{array}$ & $\begin{array}{c}\text { Company Stock } \\
\text { Code }\end{array}$ & Comparable Firm & $\begin{array}{c}\text { Fl As } \\
\text { Current }\end{array}$ & $\begin{array}{c}\text { Fl Up } \\
\mathbf{3 0 \%}\end{array}$ & $\begin{array}{c}\text { Fl Down } \\
\mathbf{2 0 \%}\end{array}$ \\
\hline 1 & CTC & & $68,1 \%$ & $88,5 \%$ & $54,5 \%$ \\
\hline 2 & DLC & DLV as comparable & $40,7 \%$ & $52,9 \%$ & $32,6 \%$ \\
\hline 3 & DLV & PGT as comparable & $63,3 \%$ & $82,3 \%$ & $50,6 \%$ \\
\hline 4 & FDT & PGT as comparable & $60,7 \%$ & $78,9 \%$ & $48,6 \%$ \\
\hline 5 & HOT & PGT as comparable & $15,6 \%$ & $20,3 \%$ & $12,5 \%$ \\
\hline 6 & PDC & & $36,2 \%$ & $47,0 \%$ & $29,0 \%$ \\
\hline 7 & PGT & & $7,1 \%$ & $9,2 \%$ & $5,6 \%$ \\
\hline 8 & TCT & & $10,1 \%$ & $13,2 \%$ & $8,1 \%$ \\
\hline 9 & TTR & & $16,3 \%$ & $21,2 \%$ & $13,0 \%$ \\
\hline 10 & MAS & & $62,6 \%$ & $81,4 \%$ & $50,1 \%$ \\
\hline & & Average & $38,1 \%$ & $49,5 \%$ & $30,5 \%$ \\
\hline
\end{tabular}

